\title{
Bone marrow malignancies as paradigms of dysfunctional cell adhesion mechanisms
}

\author{
Cachaço Ana Sofia ${ }^{1}$, Salvador Daniela ${ }^{2}$, Dias Sérgio ${ }^{3}$ \\ 1. Angiogenesis Laboratory, Centro de Investigação de Patobiologia Molecular (CIPM), Instituto Português de Oncologia de \\ Lisboa Francisco Gentil (IPOFG), Lisboa, Portugal. 2. CEDOC, Faculdade de Ciências Médicas, Universidade Nova de \\ Lisboa, Lisboa, Portugal. 3. Instituto Gulbenkian de Ciência, Oeiras, Portugal.
}

Correspondence: Sérgio Dias. Address: Angiogenesis Laboratory, Centro de Investigação de Patobiologia Molecular (CIPM), Instituto Português de Oncologia de Lisboa Francisco Gentil (IPOFG), R. Prof. Lima Basto, 1099-023 Lisboa, Portugal. Telephone: 351-217-229-818. Fax: 351-217-229-895. E-mail: sergidias@ipolisboa.min-saude.pt

Received: November 13, 2011

DOI : $10.5430 /$ jhm.v2n1p19
Accepted: December 8, 2011 Published: March 1, 2012

URL: http://dx.doi.org/10.5430/jhm.v2n1p19

\begin{abstract}
In adult bone marrow (BM), hematopoietic stem/progenitor cells (HSPCs) reside in micro-environments which provide instructions for self-renewal, survival, proliferation, differentiation and migration. Adequate response to such complex signals implies communication between HSCs, BM stroma and extracellular matrix molecules (ECM). This is achieved mainly through adhesion molecules. Malignant hematopoietic cells also interact with the BM microenvironment, which provides them with proliferative and survival advantages. Most of the studies on haematological diseases describe cell-ECM interactions as key mechanisms in tumor progression, while genetic alterations of HSC are considered major initiators of the malignant process. However, accumulating evidence suggests that an altered BM microenvironment provides anomalous cell adhesion signals, facilitating tumor initiation. Myeloproliferative and myelodysplastic syndromes are good examples of haematological disorders where alterations in BM microenvironment may play an important role in disease initiation. This review discusses the role for adhesion signals in regulating the BM microenvironment in normalcy and disease.
\end{abstract}

\section{Key words}

Bone marrow, Microenvironment, Adhesion, Extracellular matrix, Myeloproliferative syndromes, Myelodysplastic syndromes

\section{Adhesion signaling between hematopoietic cells and their microenvironment regulates hematopoiesis}

Hematopoiesis is an extremely well regulated process, ensuring the normal production of all blood cells. In adult bone marrow (BM), hematopoietic stem/progenitor cells (HSPCs) reside in particular microenvironments, known as stem cell niches, which provide them with critical instructions to self-renewal, proliferation, differentiation, homing, migration and survival (about BM niches see, as examples, the reviews ${ }^{[1-8]}$. HSPCs are believed to be located near bone surfaces (osteoblastic niche) or associated with the sinusoidal endothelium (the vascular niche); the molecular signals generated by these two niches have been extensively studied (in particular for the osteoblastic niche). Osteoblasts produce important 
signaling molecules like osteopontin and angiopoietin that interact with their receptors on HSPCs, keeping these in a quiescent state ${ }^{[9-11]}$. On the other hand, the vascular niche is considered to promote proliferation and further differentiation of HSPCs ${ }^{[12]}$; it produces FGF-4 and chemokines such as SDF-1 ${ }^{[7]}$ that recruits the HSPCs from the osteoblastic to vascular niche. Recently, with new imaging approaches, it is becoming evident that endosteal and vascular compartments may not be mutually exclusive in terms of their role on HSPC fate ${ }^{[13,14]}$.

BM microenvironment comprises not only stromal cells (including osteoblasts, endothelial cells, fibroblasts, etc), but also soluble factors produced by stromal and hematopoietic cells, and the extracellular matrix (ECM) that surrounds all BM cells. ECM is an intricate network of proteins (e.g. collagens), glycoproteins (e.g. fibronectin, laminins), glycosaminoglycans (e.g. hyaluronan) and proteoglycans (e.g. syndecans) which turnover is tightly controlled by adjacent cells (figure 1). Thus, to acquire proper information from the surrounding milieu, hematopoietic cells need to establish physical contacts through adhesion molecules expressed in a regulated fashion at cell surfaces. Such molecules can establish connections between cells and the ECM or mediate cell-cell contact. Integrins are the main receptors for ECM molecules, although others like transmembrane proteoglycans (syndecans) can function as co-receptors for the matrix. In the hematopoietic system, integrins also function as cell-cell adhesion molecules, binding to members of the immunoglobulin superfamily, like VCAM-1 (vascular cell adhesion molecule 1) or ICAM-1 (inter-cellular adhesion molecule 1). Cadherins are cell-cell adhesion proteins which established homophilic interaction between adjacent cells. Selectins exert special adhesion proprieties between leukocytes or platelets and the endothelial cells. Another group of adhesion molecules within BM comprises the sialomucins (CD34, CD43, CD45-RA, PSGL-1, CD164 and PCLP-1) and although their receptors are not completely known, the signals they deliver potently inhibit hematopoiesis ${ }^{[15,16]}$. Adhesion molecules participate in a range of signal transduction processes involving not only cell adhesion, but also migration, proliferation and apoptosis. Additionally, other signaling molecules like growth factors and cytokines can modulate cell adhesion, just as cell adhesion signaling can regulate soluble factors receptors ${ }^{[17]}$. For instance, under physiological levels of IL3 and stem cell factor (SCF), adherence of HSPC to fibronectin via $\beta 1$ integrins prevents S-phase entrance, whereas supraphysiological concentrations of these cytokines prevent p27(KIP1) elevation and override the integrin-mediated inhibition of proliferation ${ }^{[18]}$. In fact, signals produced by cytokines and chemokines regulate via an outside-in mechanism the affinity and avidity of integrins, thus providing a further level of control ${ }^{[17]}$. The chemoattractor stromal cell derived factor- $1 \alpha$ (SDF- $1 \alpha$ ) affects the function of $\beta 1$ and $\beta 2$ integrins, allowing the homing of HSPC into the BM ${ }^{[19,20]}$. Also well known is the crosstalk between growth factor receptors and integrins. Recent works on angiogenesis and tissue repair demonstrated that VEGF binding domains of fibronectin are required for promoting the specific association between the fibronectin receptor integrin $\alpha 5 \beta 1$ with the VEGF receptor, Flk-1 enhancing these biological processes (as examples see $\left.^{[21-23]}\right)$

In this review we will give special attention to the interaction between hematopoietic cells and the ECM, in particular, via integrin receptors. Such option is based on the fact that perturbations on integrin-ECM ligation occur very often in BM disorders but their importance on tumorigenesis is still not understood.

Far from being exhaustive, table 1 shows some reported cell adhesion events occurring within adult BM. For each hematopoietic cell type, the interaction between a specific receptor (e.g. integrin), expressed on its surface, and the corresponding ECM ligand or another receptor on a stromal cell, modulates hematopoietic cell behavior. Data from human or mouse models were used to compile this table. The majority of studies referred here employs in vitro approaches such as long-term BM cultures and are not always in agreement. Although a characterization of ECM molecules distribution within BM has been made by immunofluorescence labeling more than 10 years ago ${ }^{[24]}$, is still not understood if, in vivo, there is a preferential localization of different hematopoietic cells within certain ECM niches. 
Table 1. Cell-cell and cell-ECM adhesion events that modulate hematopoiesis in bone marrow

\begin{tabular}{|c|c|c|c|c|}
\hline BM cell type & $\begin{array}{l}\text { Reported } \\
\text { receptor }\end{array}$ & $\begin{array}{l}\text { ECM ligand } \\
\text { or cell } \\
\text { counter-receptor }\end{array}$ & Function & References \\
\hline \multirow[t]{10}{*}{ HSPCs } & VLA-4 & FN & \multirow{2}{*}{ Proliferation regulation, survival } & \multirow{2}{*}[25-27]{} \\
\hline & VLA-5 & FN & & \\
\hline & VLA-6 & LN-8, LN-10/11 & Migration & [28] \\
\hline & $\begin{array}{l}\text { VLA-4 } \\
B 1 \text { inteorins }\end{array}$ & FN & Regulation of multi-drug resistant genes & [29] \\
\hline & VLA-4 & VCAM-1/FN & \multirow[b]{2}{*}{ Homing, engraftment } & \multirow[b]{2}{*}{ [29-32] } \\
\hline & $\beta 1$ integrins & $\mathrm{LN} / \mathrm{FN}$ & & \\
\hline & n.d & Heparan sulphate & $\begin{array}{l}\text { Determines cytokines and ECM molecules } \\
\text { localization within stem cells niche }\end{array}$ & {$[33-35]$} \\
\hline & n.d & Tenascin & Migration inhibition & [36] \\
\hline & n.d & Osteopontin & Proliferation inhibition & [37] \\
\hline & CD164 & Lectins & Proliferation inhibition & {$[38,39]$} \\
\hline \multirow[t]{7}{*}{ Megakaryocytes } & VLA-4 & FN & Adhesion of CFU-MK and immature MKs & {$[40,41]$} \\
\hline & VLA-4 & FN & MK growth & [42] \\
\hline & VLA-5 & FN & On mature MKs & {$[40,41]$} \\
\hline & VLA-2 & Collagen & On mature polyploid MKs & {$[40,41]$} \\
\hline & $\begin{array}{l}\text { VLA-6 } \\
\alpha \operatorname{IIb} \beta 3\end{array}$ & $\begin{array}{l}\text { LN } \\
\text { Fibrinogen }\end{array}$ & Early and late MK differentiation & {$[40,41]$} \\
\hline & $\begin{array}{l}\text { VLA-4 } \\
\beta 1 \text { integrins }\end{array}$ & $\begin{array}{l}\text { VCAM-1 } \\
\text { FN }\end{array}$ & Promotion of platelet formation & {$[43,44]$} \\
\hline & VLA-2 & Collagen I & Inhibition of platelet formation & [44] \\
\hline \multirow[t]{4}{*}{ Erythrocytes } & Emp & Emp & $\begin{array}{l}\text { Erythropoiesis (apoptosis inhibition, } \\
\text { erythroblast nuclear extrusion) }\end{array}$ & {$[45,46]$} \\
\hline & ICAM-4 & $\alpha v$ integrins & $\begin{array}{l}\text { Erythropoiesis (erythroblast-central } \\
\text { macrophage interaction) }\end{array}$ & {$[47,48]$} \\
\hline & VLA-4 & VCAM-1/FN & $\begin{array}{l}\text { Erythropoiesis (erythroblast-central } \\
\text { macrophage interaction) }\end{array}$ & [49] \\
\hline & VLA-6 & LN-10/11 & Adhesion of erythroid progenitors & [28] \\
\hline \multirow[t]{4}{*}{ Myeloid cells } & VLA-6 & LN-10/11 & $\begin{array}{l}\text { Adhesion of myelonocytic progenitors and } \\
\text { myeloid cell lines }\end{array}$ & [28] \\
\hline & n.d & Collagen & Myelopoiesis inhibition & {$[50]$} \\
\hline & VLA-4 & FN & Development of myeloid lineages & [50] \\
\hline & VLA-4 & n.d. & Leukocyte development and traffic & [51] \\
\hline \multirow[t]{2}{*}{ Lymphoid cells } & $\begin{array}{l}\text { VLA-4 } \\
\text { VLA-5 }\end{array}$ & $\begin{array}{l}\text { VCAM-1/FN } \\
\text { FN }\end{array}$ & B-cell development & {$[52-57]$} \\
\hline & VLA-4 & VCAM-1 & T-cell development & {$[58,55]$} \\
\hline
\end{tabular}

Abbreviations. CFU-MK=colony-forming unit-megakaryocyte; Emp=erythroblast macrophage protein, FN=fibronectin; HSPCs=Hematopoietic stem/progenitor cells; ICAM-4=inter-cellular adhesion molecule 4; LN=laminin; MKs=megakaryocytes; VCAM-1=vascular cell adhesion molecule 1; VLA-2=very late antigen 2, $\alpha 2 \beta 1$ integrin; VLA-4=very late antigen 4, $\alpha 4 \beta 1$ integrin; VLA-5=very late antigen $5, \alpha 5 \beta 1$ integrin; VLA-6=very late antigen $6, \alpha 6 \beta 1$ integrin; n.d.=Not determined on that particular study 
Table 2. Cell adhesion interactions between malignant cells and stromal cells/ECM and their potential importance in hematological malignancies

\begin{tabular}{|c|c|c|c|}
\hline Group & Cell receptor-ligand expression* & Reported effect on leukemic cells & References \\
\hline \multirow[t]{5}{*}{ AML } & $\begin{array}{l}\text { VLA-4, -5-FN, VLA-6-LN, } \\
\text { LFA-1-ICAMs }\end{array}$ & Adhesion, survival & [67- 72] \\
\hline & $\begin{array}{l}\text { Altered function/affinity of VLA-4, } \\
-5 \text {-FN }\end{array}$ & AML blasts release intocirculation & {$[70,73]$} \\
\hline & VLA-4-LN & Protection against chemotherapy & {$[64,74]$} \\
\hline & Expression of different CD44 isoforms & Adhesion, proliferation & {$[75,76]$} \\
\hline & CD44-hyaluronan & Proliferation inhibition and terminal differentiation & {$[77-80]$} \\
\hline \multirow[t]{3}{*}{ CML } & VLA-4, -5 inactivation & Expansion and premature release of blasts from BM & {$[81-86]$} \\
\hline & Expression of different CD44 isoforms & $\begin{array}{l}\text { Early differentiation-associated changes in CML } \\
\text { CFU-GM }\end{array}$ & [87] \\
\hline & $\beta$ integrins-FN & Drug resistance & {$[88,89]$} \\
\hline \multirow[t]{2}{*}{ ALL } & VLA-4-VCAM-1, VLA-5-FN & Adhesion, proliferation and migration & [68-95] \\
\hline & Increased CD44 & Adhesion & {$[96,97]$} \\
\hline \multirow[t]{3}{*}{ CLL } & VLA-4-VCAM- $1 ; \beta 2$ integrins & Endothelial extravasation & {$[98,99]$} \\
\hline & VLA-4-VCAM-1/FN, $\beta 2$ integrins & Apoptosis inhibition, disease relapse & [100-102] \\
\hline & Increased CD44 & Protection from apoptosis; poor prognosis & {$[103-105]$} \\
\hline \multirow[t]{6}{*}{ MM } & LFA-1-ICAM-1 & Cell aggregation, proliferation & {$[106,107]$} \\
\hline & $\begin{array}{l}\text { VLA-4-VCAM-1/FN, VLA-5-FN, } \\
\text { VLA-6-LN }\end{array}$ & $\begin{array}{l}\text { Transendothelial migration, retention of MM cells in } \\
\text { BM }\end{array}$ & [108-111] \\
\hline & VLA-5 down-regulation & $\begin{array}{l}\text { Exit of MM cells to extramedullar places (at later } \\
\text { stages) }\end{array}$ & {$[112]$} \\
\hline & VLA-4-FN & Drug resistance & {$[113-115]$} \\
\hline & $\begin{array}{l}\text { CD44 (different isoforms)/ } \\
\text { RHAMM-hyaluronan }\end{array}$ & Adhesion and migration & [116-120] \\
\hline & Syndecan-1 & Multifunctional regulator of MM microenvironment & {$[121-123]$} \\
\hline
\end{tabular}

Abbreviations. $\mathrm{ALL}=$ acute lymphoblastic leukemia; $\mathrm{AML}=$ acute myeloid leukemia; $\mathrm{CFU}-\mathrm{GM}=$ colony-forming units granulocyte-macrophage; $\mathrm{CLL}=$ chronic lymphocytic leukemia; $\mathrm{CML}=$ chronic myelogenous leukaemia; FN=fibronectin; ICAM=inter-cellular adhesion molecule; LFA-1=lymphocyte function-associated antigen $-1, \alpha \mathrm{L} \beta 2$ integrin; LFA-3= lymphocyte function-associated antigen - 3; LN=laminin; MM=multiple myeloma; NCAM=neural cell adhesion molecule; VLA-3= very late antigen 3, $\alpha 3 \beta 1$ integrin; VLA-4=very late antigen 4, $\alpha 4 \beta 1$ integrin; VLA-5 = very late antigen $5, \alpha 5 \beta 1$ integrin; VLA- $6=$ very late activated- $6, \alpha 6 \beta 1$ integrin

* In some situations, only the malignant cell receptor is referred and not its ligand

\section{Dysregulation of adhesion signaling between hematopoietic cells and their microenvironment is involved in hematological disorders}

Malignant hematopoietic cells are known to express particular cell adhesion repertoires that provide them with proliferative and survival advantages within the BM microenvironment. Specific niche composition provides ideal 
conditions for some leukemic cells to escape from chemotherapy-induced apoptosis and acquire drug-resistance. On this subject, several reviews can be consulted, for instance: ${ }^{[59-61]}$. Most of the studies on leukemias and other hematological diseases refer integrins and their ligation with ECM or stromal cells as key mechanisms involved in tumor progression; well identified genetic hits occurring on HSCs would be the major beginners of the oncogenic process (see, as examples ${ }^{[62,63]}$. Presently, the acceptance that the BM microenvironment is important in supporting leukemia stem cells survival has conducted to the rational development of therapies that target microenvironment molecules ${ }^{[59,60]}$. For instance, the inhibition of VLA-4 integrin - fibronectin ligation in in acute myeloid leukemia (AML) patients increases their sensibility to chemotherapy ${ }^{[64]}$. Also, adhesion molecules profiles of hematological patients are presently being considering, since variations among them may have important clinical consequences.

In table 2 we summarize major cell adhesion interactions that occur between BM malignant cells and ECM or stromal cells, contributing to hematological diseases. In some situations, like in multiple myeloma, perturbations in cell-ECM adhesion take place, like dysregulation of integrin function or upregulation of different ECM receptors, leading to aberrant behaviors and clonal expansion of the malignant cells. In other cases, like in some leukemias, the same receptor-ECM ligation occurs in normal and in malignant cells, but malignant cells acquire proliferative and survival advantages upon normal cells, replacing them. This suggests that such advantages may be supported by modifications in BM microenvironment that normal cells are not able to cope with, using the common adhesion pathways. In agreement with this, two early in vitro studies showed that leukemia-derived stromal cells could not sustain appropriate maturation of normal HSPCs ${ }^{[65,66]}$.

\section{Role of BM microenvironment in the onset of tumorigenesis - two examples from non-malignant disorders}

There are growing evidences that an altered microenvironment may not only support tumor progression, but can also facilitate tumor initiation providing anomalous cell adhesion signaling. Few recent works on epithelial cancers suggest that ECM can not only subsidize but also initiate the oncogenic conversion of epithelial cells ${ }^{[124]}$. One possible cause for such tumor-driven ECM alterations may be irreversible damages (repeated traumas, fibrosis, inflammation, etc) in stroma or other sources of ECM. Some hematological disorders are characterized by an altered stroma, in particular an accumulation of ECM molecules, like in primary or idiopatic myelofibrosis (PMF). Additionally, fibrosis can also occur as a secondary event in some leukemias, which is associated with bad prognosis. In an interesting review, Dührsen and Hossfeld ${ }^{[125]}$ define two mechanisms for hematological tumorigenesis: "malignancy-induced microenvironment" and "malignancy-inducing microenvironment". In the first case, neoplastic hematopoietic cells induce alterations in BM microenvironment that became permissive to malignant clone expansion. In the second case, the first event includes a stroma lesion which restrains normal hematopoietic cell regulation, leading to the emergence of a neoplastic cell population. In accordance, perturbations in BM niche signaling in mouse models were shown to mimic human diseases ${ }^{[126,127]}$.

In this section we will provide two examples of hematological disorders where microenvironment, and adhesion signaling in particular, may have an important role in the initiation of the malignant phenotype. That is particular evident and has been extensively studied for PMF, a myeloproliferative syndrome (MPS), and also for myelodysplasic syndromes (MDS).

MPS are a group of BM clonal diseases with enhanced proliferation and survival of one or more cells types of the myeloid lineage. They are categorized by the presence or absence of the Philadelphia chromosome (t9;22), and include, among 
others, PMF, polycythemia vera (PV), essential thrombocythemia (ET) (all Philadelphia chromosome-negative) and chronic myelogenous leukemia (CML - Philadelphia chromosome-positive) ${ }^{[63,128]}$. A complete genetic and clinicopathological classification of this group of disorders is out of the scope of this review and can be consulted, for instance, in ${ }^{[63,129,130]}$. In PMF, both initial prefibrotic (not associated with reticulin accumulation) and more advanced myelofibrotic stages show increased abnormal megakaryo- and granulopoiesis; atypical megakaryocytes (MKs) are clustered and medium-sized to giant, with cloud-like, and often hyperchromatic nuclei, a feature not seen in other subtypes of MPS ${ }^{[130-132]}$. MKs promote fibroblast growth, a mechanism where cell-cell contact mediated by integrins VLA-3 and VLA-5 is implicated ${ }^{[133]}$. More, the abnormal MKs release specific growth factors (like TGF- $\beta$ ) that enhance ECM production by fibroblasts ${ }^{[134,135]}$. In a typical case of PMF, hematopoietic cells in BM are replaced by collagen fibrosis (although other ECM proteins, like fibronectin, are also increased), impairing the patient ability to generate new blood cells; this results in progressive pancytopenia, extramedullary hematopoiesis and splenomegaly. A significant inverse correlation between fibre content and number of HSPCs in BM has been established in PMF ${ }^{[136]}$. Not only increased production of ECM occurs in PMF but there is also an imbalance between metalloproteases (MMPs) and TIMPs (MMPs inhibitors) that may contribute to BM niche, probably through perturbations in HSPCs-ECM adhesion, is of outmost importance for disease development ${ }^{[137]}$.

MDS are a heterogenous group of clonal hematopoietic diseases characterized by peripheral cytopenia (despite a normocellular or hypercellular BM) and with a variable probability to progress to $\mathrm{AML}^{[138,139]}$. In the past decade, it has become apparent that this ineffective hematopoiesis is largely caused by excessive apoptosis of myeloid precursors ${ }^{[140-143]}$. Recent observations suggest that downregulation of VLA-4 and VLA-5 integrins on HSPCs, correlated with decreased in vitro adhesiveness to fibronectin fragments, can act as a pro-apoptotic mechanism in MDS ${ }^{[144]}$. It is possible that these alterations in the adhesive proprieties of myeloid progenitors are cell-autonomous and confer cell susceptibility to apoptosis ${ }^{[145]}$. However, changes in BM stroma, namely on ECM, have already been detected in some MDS patients, suggesting again a role for microenvironment in MDS progression ${ }^{[146,147]}$. In a considerable percentage of biopsies, myeloid precursors are found in an abnormal central localization within the BM, instead of being near the osteoblastic niche, a feature associated with poor disease prognosis ${ }^{[148,149]}$. Nevertheless, the question remains: Are microenvironment alterations the initial event that dysregulates hematopoiesis in MDS? Studies using normal cord blood cells cultivated with BM stromal cells from patients with childhood MDS show aberrant cell differentiation of precursor cells; here, stroma cells expressed increased levels of thrombospondin-1, collagen -I $\alpha 2$-chain, osteoblast-specific factor-2 and osteonectin, indicating the presence of increased osteoblast content that may contribute to abnormal hematopoiesis in this pathology ${ }^{[150]}$. In another in vitro study, both fibroblasts and macrophages from MDS BM are functionally abnormal, denoting increased apoptosis and high production of both IL-6 and TNF- $\alpha{ }^{[151]}$. Like for PMF, megakaryocytic proliferation and differentiation are typically abnormal in patients with $\mathrm{MDS}^{[152]}$, being thrombocytopenia one of the first features of this syndrome. Also, the expression of the stem cell marker CD34 on mature MKs from MDS patients is correlated with reduced survival ${ }^{[153]}$. Other adhesion molecule patterns are modified in HSPCs from MDS and secondary AML, like ICAM-1 (overexpressed) and L-selectin (underexpressed), having prognosis importance ${ }^{[154]}$. Also, plasma levels of soluble CD44 are significantly elevated in MDS patients as compared to those of healthy donors and are increased in high-risk MDS subtypes ${ }^{[155]}$.

While pro-apoptotic mechanisms are activated in HSPCs in MDS, the evolution to an aggressive AML includes a suppression of apoptosis due to changes in intracellular levels of Bcl-2-family proteins ${ }^{[156,143]}$. Nevertheless, important interactions between leukemic cells and BM microenvironment also contribute to AML progression: When natural killer cells and cytotoxic lymphocytes adhere to BM stroma, they inhibit AML blasts clonogenic growth; however, AML cells compete with them for stromal binding sites via $\beta 1$ (principally VLA-4) and $\beta 2$ integrins, escaping from 
apoptosis ${ }^{[70,72,157]}$. Finally, in advanced stages, the lost of contact with ECM is necessary for AML blasts to egress to circulation $^{[158]}$.

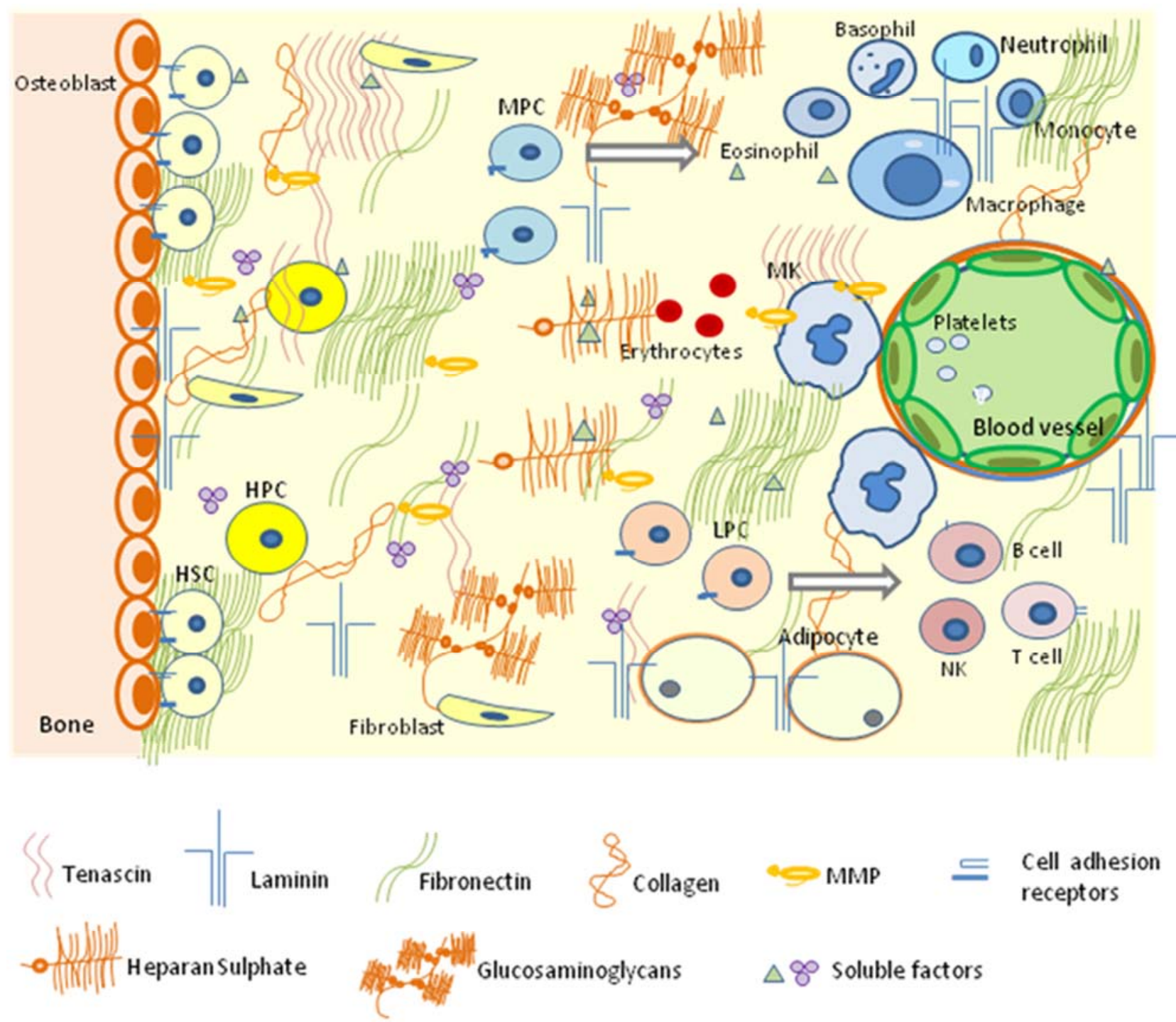

Figure 1. Schematic representation of major steps in hematopoiesis within BM microenvironment. The image represents BM niches: the osteoblastic niche, where quiescent hematopoietic stem cells (HSC) and hematopoietic progenitor cells (HPC) localize, and the vascular niche, where HPC differentiation occurs. Myeloid progenitor cells (MPC) originate basophils, neutrophils, eosino-phils, monocytes, megakaryocytes (MKs - which give rise to platelets), and erythrocytes; lympho-cyte progenitor cells (LPC) originate lymphocytes B and T, and natural killer cell (NK) cell. BM microenvironment is composed by ECM proteins like collagen $(\mathrm{Col})$, glycoproteins as fibronectin (FN), laminin (LN) and tenascin (TN), glycosaminoglycans (GAGs), and proteoglycans (PG); it also contains soluble factors like growth factors (GF) and matrix metalloproteases (MMPs), and stroma cells (endothelial cells, osteoblasts, fibroblasts, macrophages, adipocytes). Hematopoietic cells associate with ECM molecules throughout cell adhesion receptors (CAR), like integrins. 
A

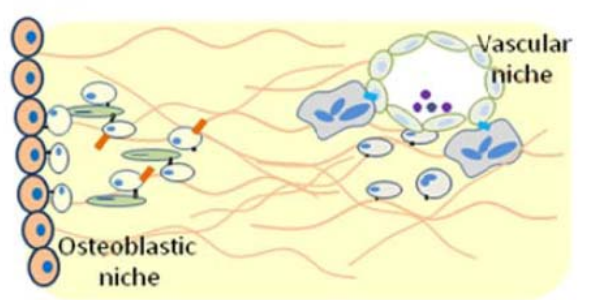

B

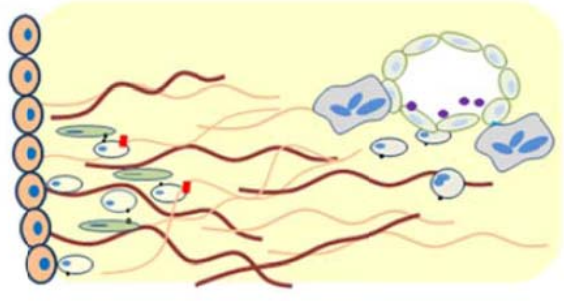

D

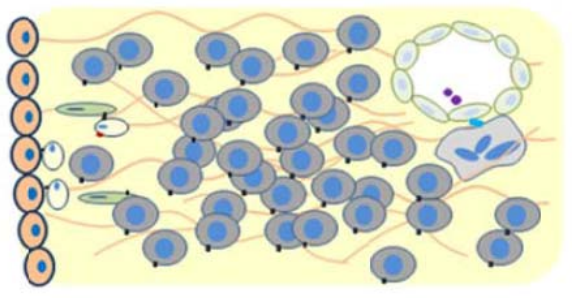

Differentiated hematopoietic cells

Malignant cell

Apoptotic cell

Figure 2. Hematopoietic malignancies are paradigms of dysfunctional cell adhesion mechanisms within bone marrow (BM) microenvironment. A. In a steady-state BM, hematopoietic cells are located in their niches and established appropriated cell-cell and cell-extracellular matrix (ECM) connections with BM microenvironment. B. Alterations in ECM turnover and qualitative and/or quantitative changes in cell adhesion molecules contribute to an unstable BM microenvironment where incorrect cell adhesion pathways/mechanisms occur. C. This situation may create a premalignant condition within BM, characterized by aberrant haematopoiesis, including increased apoptosis. D. BM dysfunction favours clonal selection of malignant hematopoietic cells and leads to the onset and progression of fatal haematological diseases.

\section{Final remarks}

According to Dührsen and Hossfeld ${ }^{[125]}$, MDS most likely result from a primary lesion in BM stroma, which results in the creation of an unstable microenvironment. Lack of adequate adhesion signals (among others), generates a "suicidal" environment for most hematopoietic cells in the BM; increased sensitivity to apoptosis is a hallmark of MDS. Remarkably, increased cell death is followed by increased proliferation, likely of selected and well adapted cell clones. The generation of such an unstable microenvironment may in fact result in the establishment of a pre-malignant condition. In fact, MDS can progress to AML while PMF can be associated with advanced stages of ET, PV and CLL, representing poor prognosis.

Fibroblasts have been regarded as major producers of ECM in the BM, although an early publication showed the distribution of fibronectin, type I, type III and type V collagens is similar in cultured BM fibroblasts from normal and from MPS patients with and without myelofibrosis [159] Interestingly, MKs are important producers of MMPs [160], fibronectin ${ }^{[161]}$, (our unpublished results), and thrombospondin-1 ${ }^{[162]}$, and they are dysfunctional both in MDS and PMF ${ }^{[153]}$. This fact raises the possibility that MKs may play a crucial role in regulating ECM turnover, in normal, pre-malignant and in malignant BM. 
Two important reports using mice as models have demonstrated that events extrinsic to HSPCs modify BM microenvironment and are the sole cause of an MPS phenotype. One is the loss of the retinoic acid receptor- $\gamma^{[126]}$ and the other is due to a retinoblastoma protein-dependent interaction between myeloid-derived cells and the microenvironment ${ }^{[127]}$. Recently, our own studies showed that increased TNF- $\alpha$ levels occurring in BM microenvironment after radiation contribute towards the onset and progression of secondary MDS in mice ${ }^{[163]}$. The latter report indicated that ECM turnover is altered in irradiated (pre-malignant) BM, and that this contributes towards the onset of hematological dysfunction.

In this review, we have provided examples where hematological malignancies may be seen as paradigms of dysfunctional cell and tissue microenvironments, involving cell-ECM and cell-cell interations, including those mediated by adhesion molecules. Taken together, we propose a tight regulation of the mechanisms that govern cell adhesion to ECM and to other components of the BM microenvironment is essential to assure adequate BM function; conversely, changes in adhesion signaling pathways/mechanisms may contribute towards the generation of a pre-malignant microenvironment and to the onset and progression of fatal hematological diseases (figure 2).

\section{Acknowledgements}

A.S. Cachaço is funded by a Fundação para a Ciência e a Tecnologia (FCT) fellowship (SFRH / BPD / 42056 / 2007). Work in the Angiogenesis Lab focusing on the BM microenvironment is funded by FCT, the Gulbenkian Foundation and Associação Portuguesa Contra a Leucemia (APCL).

\section{Conflict of interest}

The authors have declared that no competing interests exist.

\section{References}

[1] Carlesso N, Cardoso AA. Stem cell regulatory niches and their role in normal and malignant hematopoiesis. Curr Opin Hematol 2010;17:281-86. PMid: 20473160. http://dx.doi.org/10.1097/MOH.0b013e32833a25d8

[2] Arai F, Suda T. Maintenance of quiescent hematopoietic stem cells in the osteoblastic niche. Ann N Y Acad of Sci 2007;1106:41-53. PMid: 17332071. http://dx.doi.org/10.1196/annals.1392.005

[3] Scadden DT. The stem cell niche in health and leukemic disease. Best Pract Res Clin Haematol 2007; 20:19-27. http://dx.doi.org/10.1016/j.beha.2006.11.001

[4] Kacena MA, Gundberg CM, Horowitz MC. A reciprocal regulatory interaction between megakaryocytes, bone cells, and hematopoietic stem cells. Bone 2006;39:978-84. PMid: 16860008. http://dx.doi.org/10.1016/j.bone.2006.05.019

[5] Moore KA, Lemischka IR. Stem cells and their niches. Science 2006;311:1880-85. PMid: 16574858. http://dx.doi.org/10.1126/science.1110542

[6] Wilson A, Trumpp A. Bone-marrow haematopoietic-stem-cell niches. Nat Rev Immun 2006;6:93-106. PMid: 16491134. http://dx.doi.org/10.1038/nri1779

[7] Yin T, Li L. The stem cell niches in bone. J Clin Invest 2006;116:1195-201. PMid: 16670760. http://dx.doi.org/10.1172/JCI28568

[8] Li L, Xie T. Stem cell niche: structure and function. Annu Review Cell Dev Biol 2005;21:605-31. PMid: 16212509. http://dx.doi.org/10.1146/annurev.cellbio.21.012704.131525

[9] J Grassinger, Haylock DN, Storan MJ, Haines GO, Williams B, Whitty GA, Vinson AR, Be CL, Li S, Sørensen ES, Tam PP, Denhardt DT, Sheppard D, Choong PF, Nilsson SK. Thrombin-cleaved osteopontin regulates hemopoietic stem and progenitor cell functions through interactions with alpha9beta1 and alpha4beta1 integrins. Blood 2009;114:49-59. PMid: 19417209. http://dx.doi.org/10.1182/blood-2009-01-197988 
[10] Arai F, Hirao A, Suda T. Regulation of hematopoiesis and its interaction with stem cell niches. Int J Hemato 2005;82:371-76. PMid:16533737. http://dx.doi.org/10.1532/IJH97.05100

[11] Suda T, Arai F, Shimmura S. Regulation of stem cells in the niche. Cornea. 2005;24:S12-S17. PMid: 16227817. http://dx.doi.org/10.1097/01.ico.0000178742.98716.65

[12] Kopp HG, Avecilla ST, Hooper AT, Rafii S. The bone marrow vascular niche: home of HSC differentiation and mobilization. Physiology (Bethesda) 2005;20:349-56. PMid: 16174874. http://dx.doi.org/10.1152/physiol.00025.2005

[13] Lo Celso C, Fleming HE, Wu JW, Zhao CX, Miake-Lye S, Fujisaki J, Côté D, Rowe DW, Lin CP, Scadden DT. Live-animal tracking of individual haematopoietic stem/progenitor cells in their niche. Nature 2009;457:92-96. PMid: 19052546. http://dx.doi.org/10.1038/nature07434

[14] Xie Y, Yin T, Wiegraebe W, He XC, Miller D, Stark D, Perko K, Alexander R, Schwartz J, Grindley JC, Park J, Haug JS, Wunderlich JP, Li H, Zhang S, Johnson T, Feldman RA, Li L. Detection of functional haematopoietic stem cell niche using real-time imaging. Nature 2009;457:97-101. PMid: 19052548. http://dx.doi.org/10.1038/nature07639

[15] Simmons PJ, Levesque JP Haylock DN. Mucin-like molecules as modulators of the survival and proliferation of primitive hematopoietic cells. Ann N Y Acad Sci. 2001;938:196-206. http://dx.doi.org/10.1111/j.1749-6632.2001.tb03590.x

[16] Simmons PJ, Levesque JP, Zannettino AC. Adhesion molecules in haemopoiesis. Baillieres Clin Haematol 1997;10:485-505. http://dx.doi.org/10.1016/S0950-3536(97)80022-4

[17] Prosper F, Verfaillie CM. Regulation of hematopoiesis through adhesion receptors. J Leukoc Biol 2001;69:307-16. PMid: 11261776.

[18] Jiang Y, Prosper F, Verfaillie CM. Opposing effects of engagement of integrins and stimulation of cytokine receptors on cell cycle progression of normal human hematopoietic progenitors. Blood 2000;95:846-54. PMid: 10648395.

[19] Naiyer AJ, Jo DY, Ahn J, Mohle R, Peichev M, Lam G, Silverstein RL, Moore MA, Rafii S. Stromal derived factor-1-induced chemokinesis of cord blood CD34(+) cells (long-term culture-initiating cells) through endothelial cells is mediated by E-selectin. J Insur Med 2008;40:218-28. PMid: 19317331.

[20] Peled A, Grabovsky V, Habler L, Sandbank J, Arenzana-Seisdedos F, Petit I, Ben-Hur H, Lapidot T, Alon R. The chemokine SDF-1 stimulates integrin-mediated arrest of CD34(+) cells on vascular endothelium under shear flow. J Clin Invest 1999;104:1199-211. PMid: 10545519.

[21] Martino MM, Tortelli F, Mochizuki M, Traub S, Ben-David D, Kuhn GA, Müller R, Livne E, Eming SA, Hubbell JA. Engineering the growth factor microenvironment with fibronectin domains to promote wound and bone tissue healing. Sci Transl Me 2011;3:100ra89.

[22] Lee S, Jilani SM, Nikolova GV, Carpizo D, Iruela-Arispe ML. Processing of VEGF-A by matrix metalloproteinases regulates bioavailability and vascular patterning in tumors. J Cell Biol 2005;169:681-91. PMid: 15911882. http://dx.doi.org/10.1083/jcb.200409115

[23] Wijelath ES, Murray J, Rahman S, Patel Y, Ishida A, Strand K, Aziz S, Cardona C, Hammond WP, Savidge GF, Rafii S, Sobel M. Novel vascular endothelial growth factor binding domains of fibronectin enhance vascular endothelial growth factor biological activity. Circ Res 2002;91:25-31. PMid: 12114318. http://dx.doi.org/10.1161/01.RES.0000026420.22406.79

[24] Nilsson SK, Debatis ME, Dooner MS, Madri JA, Quesenberry PJ, Becker PS. Immunofluorescence characterization of key extracellular matrix proteins in murine bone marrow in situ. J Histochem Cytochem 1998;46:371-77. http://dx.doi.org/10.1177/002215549804600311

[25] Jung Y, Wang J, Havens A, Sun Y, Wang J, Jin T, Taichman RS. Cell-to-cell contact is critical for the survival of hematopoietic progenitor cells on osteoblasts. Cytokine 2005;32:155-62. PMid: 16256361. http://dx.doi.org/10.1016/j.cyto.2005.09.001

[26] Yokota T, Oritani K, Mitsui H, Aoyama K, Ishikawa J, Sugahara H, Matsumura I, Tsai S, Tomiyama Y, Kanakura Y, Matsuzawa Y. Growth-supporting activities of fibronectin on hematopoietic stem/progenitor cells in vitro and in vivo: structural requirement for fibronectin activities of CS1 and cell-binding domains. Blood 1998;91:3263-72. PMid: 9558382.

[27] Hurley RW, McCarthy JB, Verfaillie CM. Direct adhesion to bone marrow stroma via fibronectin receptors inhibits hematopoietic progenitor proliferation. J Clin Invest 1995; 96:511-19. PMid: 7542285. http://dx.doi.org/10.1172/JCI118063 
[28] Gu YC, Kortesmaa J, Tryggvason K, Persson J, Ekblom P, Jacobsen SE, Ekblom M. Laminin isoform-specific promotion of adhesion and migration of human bone marrow progenitor cells. Blood 2003;101:877-85. PMid: 12393739. http://dx.doi.org/10.1182/blood-2002-03-0796

[29] Sagar BM, Rentala S, Gopal PN, Sharma S, Mukhopadhyay A. Fibronectin and laminin enhance engraftibility of cultured hematopoietic stem cells. Biochem Biophys Res Commun 2006;350:1000-05. PMid: 17045241. http://dx.doi.org/10.1016/j.bbrc.2006.09.140

[30] Hidalgo A, Sanz-Rodríguez F, Rodríguez-Fernández JL, Albella B, Blaya C, Wright N, Cabañas C, Prósper F, Gutierrez-Ramos JC, Teixidó J. Chemokine stromal cell-derived factor-1alpha modulates VLA-4 integrin-dependent adhesion to fibronectin and VCAM-1 on bone marrow hematopoietic progenitor cells. Exp Hematol 2001;29:345-55. http://dx.doi.org/10.1016/S0301-472X(00)00668-8

[31] Potocnik AJ, Brakebusch C, Fässler R. Fetal and adult hematopoietic stem cells require betal integrin function for colonizing fetal liver, spleen, and bone marrow. Immunity 2000;12:653-63. http://dx.doi.org/10.1016/S1074-7613(00)80216-2

[32] Papayannopoulou T, Craddock C. Homing and trafficking of hemopoietic progenitor cells. Acta Haematol 1997;97:97-104. PMid: 8980615. http://dx.doi.org/10.1159/000203665

[33] Bramono DS, Rider DA, Murali S, Nurcombe V, Cool SM. The effect of human bone marrow stroma-derived heparan sulfate on the ex vivo expansion of human cord blood hematopoietic stem cells. Pharm Research 2011;28:385-94. PMid: 21184148. http://dx.doi.org/10.1007/s11095-010-0352-y

[34] Gupta P, Oegema TR, Brazil JJ, Dudek AZ, Slungaard A, Verfaillie CM. Structurally specific heparan sulfates support primitive human hematopoiesis by formation of a multimolecular stem cell niche. Blood 1998;92:4641-51. PMid: 9845530.

[35] Coombe DR. The role of stromal cell heparan sulphate in regulating haemopoiesis. Leuk Lymphoma 1996;21:399-406. http://dx.doi.org/10.3109/10428199609093437

[36] Klein G, Beck S, Müller CA. Tenascin is a cytoadhesive extracellular matrix component of the human hematopoietic microenvironment. J Cell Biol 1993;123:1027-35. PMid: 7693718. http://dx.doi.org/10.1083/jcb.123.4.1027

[37] Stier S, Ko Y, Forkert R, Lutz C, Neuhaus T, Grünewald E, Cheng T, Dombkowski D, Calvi LM, Rittling SR, Scadden DT. Osteopontin is a hematopoietic stem cell niche component that negatively regulates stem cell pool size. J Exp Med 2005;201:1781-91. PMid: 15928197. http://dx.doi.org/10.1084/jem.20041992

[38] Watt SM, Chan JY. CD164--a novel sialomucin on CD34+ cells. Leuk Lymphoma 2000;37:1-25. http://dx.doi.org/10.3109/10428190009057625

[39] Zannettino AC, Bühring HJ, Niutta S, Watt SM, Benton MA, Simmons PJ. The sialomucin CD164 (MGC-24v) is an adhesive glycoprotein expressed by human hematopoietic progenitors and bone marrow stromal cells that serves as a potent negative regulator of hematopoiesis. Blood 1998;92:2613-28. PMid: 9763543.

[40] Molla A, Mossuz P, Berthier R. Extracellular matrix receptors and the differentiation of human megakaryocytes in vitro. Leuk Lymphoma 1999;33:15-23. PMid: 10194117.

[41] Mossuz P, Schweitzer A, Molla A, Berthier R Expression and function of receptors for extracellular matrix molecules in the differentiation of human megakaryocytes in vitro. Br J Haematol 1997;98:819-27. PMid: 9326173. http://dx.doi.org/10.1046/j.1365-2141.1997.3013118.x

[42] Fox NE, Kaushansky K Engagement of integrin alpha4beta1 enhances thrombopoietin-induced megakaryopoiesis. Exp Hematol 2005;33:94-99. PMid: 15661402. http://dx.doi.org/10.1016/j.exphem.2004.10.002

[43] Pallotta I, Lovett M, Rice W, Kaplan DL, Balduini A. Bone marrow osteoblastic niche: a new model to study physiological regulation of megakaryopoiesis. PloS one 2009;4:e8359. PMid: 20027303. http://dx.doi.org/10.1371/journal.pone.0008359

[44] Berthier R, Jacquier-Sarlin M, Schweitzer A, MR. Block, Molla A. Adhesion of mature polyploid megakaryocytes to fibronectin is mediated by beta 1 integrins and leads to cell damage. Exp Cell Res 1998;242:315-27. PMid: 9665829. http://dx.doi.org/10.1006/excr.1998.4119

[45] Soni S, Bala S, Gwynn B, Sahr KE, Peters LL, Hanspal M. Absence of erythroblast macrophage protein (Emp) leads to failure of erythroblast nuclear extrusion. J Biol Chem 2006;281: 20181-89. PMid: 16707498. http://dx.doi.org/10.1074/jbc.M603226200 
[46] Hanspal M, Hanspal JS. The association of erythroblasts with macrophages promotes erythroid proliferation and maturation: a 30-kD heparin-binding protein is involved in this contact. Blood 1994;84:3494-504. PMid:7949103

[47] Lee G, Lo A, Short SA, Mankelow TJ, Spring F, Parsons SF, Yazdanbakhsh K, Mohandas N, Anstee DJ, Chasis JA. Targeted gene deletion demonstrates that the cell adhesion molecule ICAM-4 is critical for erythroblastic island formation. Blood 2006;108:2064-71. PMid: 16690966. http://dx.doi.org/10.1182/blood-2006-03-006759

[48] Lee G, Spring FA, Parsons SF, Mankelow TJ, Peters LL, Koury MJ, Mohandas N, Anstee DJ, Chasis JA. Novel secreted isoform of adhesion molecule ICAM-4: potential regulator of membrane-associated ICAM-4 interactions. Blood 2003;101:1790-97. PMid: 12406883. http://dx.doi.org/10.1182/blood-2002-08-2529

[49] Sadahira Y, Yoshino T, Monobe Y. Very late activation antigen 4-vascular cell adhesion molecule 1 interaction is involved in the formation of erythroblastic islands. J Exp Med 1995;181:411-15. PMid: 7528776. http://dx.doi.org/10.1084/jem.181.1.411

[50] Hassan HT, Sadovinkova EY, Drize NJ, Zander AR, Neth R. Fibronectin increases both non-adherent cells and CFU-GM while collagen increases adherent cells in human normal long-term bone marrow cultures. Haematologia. 1997;28:77-84.

[51] Arroyo AG, Taverna D, Whittaker CA Strauch UG, Bader BL, Rayburn H, Crowley D, Parker CM, Hynes RO. In vivo roles of integrins during leukocyte development and traffic: insights from the analysis of mice chimeric for alpha 5 , alpha $\mathrm{v}$, and alpha 4 integrins. J Immunol 2000;165:4667-75. PMid: 11035110.

[52] Hahn BK, Piktel D, Gibson LF, Landreth KS. Hematopoiesis: The Role of Stromal Integrin Interactions in Pro-B Cell Proliferation. Hematology 2000;5:153-160. PMid: 11399610.

[53] Arroyo AG, Yang JT, Rayburn H, Hynes RO. Alpha4 integrins regulate the proliferation/differentiation balance of multilineage hematopoietic progenitors in vivo. Immunity 1999;11:555-66. http://dx.doi.org/10.1016/S1074-7613(00)80131-4

[54] De Waele M, Renmans W, Damiaens S, Flament J, Schots R, Van Riet I. Different expression of adhesion molecules on myeloid and B-lymphoid CD34+ progenitors in normal bone marrow. Eur J Haematol 1997;59:277-86. http://dx.doi.org/10.1111/j.1600-0609.1997.tb01687.x

[55] Arroyo AG, Yang JT, Rayburn H, Hynes RO. Differential requirements for alpha4 integrins during fetal and adult hematopoiesis. Cell 1996;85:997-1008. http://dx.doi.org/10.1016/S0092-8674(00)81301-X

[56] Dittel BN, McCarthy JB, Wayner EA, LeBien TW. Regulation of human B-cell precursor adhesion to bone marrow stromal cells by cytokines that exert opposing effects on the expression of vascular cell adhesion molecule-1 (VCAM-1). Blood 1993;81:2272-82. PMid:7683214

[57] Miyake K, Weissman IL, Greenberger JS, Kincade PW Evidence for a role of the integrin VLA-4 in lympho-hemopoiesis. J Exp Med 1991;173:599-607. PMid: 1997648. http://dx.doi.org/10.1084/jem.173.3.599

[58] Salomon DR, Crisa L, Mojcik CF, Ishii JK, Klier G, Shevach EM. Vascular cell adhesion molecule-1 is expressed by cortical thymic epithelial cells and mediates thymocyte adhesion. Implications for the function of alpha4beta1 (VLA4) integrin in T-cell development. Blood 1997;89:2461-71. PMid:9116290

[59] Konopleva M, Tabe Y, Zeng Z, Andreeff M. Therapeutic targeting of microenvironmental interactions in leukemia: mechanisms and approaches. Drug Resist Update 2009;12:103-13. PMid: 19632887. http://dx.doi.org/10.1016/j.drup.2009.06.001

[60] Lane SW, Scadden DT, Gilliland DG. The leukemic stem cell niche: current concepts and therapeutic opportunities. Blood 2009;114:1150-57. PMid: 19401558. http://dx.doi.org/10.1182/blood-2009-01-202606

[61] Rizo A, Vellenga E, de Haan G, Schuringa JJ. Signaling pathways in self-renewing hematopoietic and leukemic stem cells: do all stem cells need a niche? Hum Mol Genet 2006;15:R210-19. PMid: 16987886. http://dx.doi.org/10.1093/hmg/ddl175

[62] Kennedy JA, Barabé F. Investigating human leukemogenesis: from cell lines to in vivo models of human leukemia. Leukemia 2008;22:2029-40. PMid: 18685615. http://dx.doi.org/10.1038/leu.2008.206

[63] Tefferi A, Gilliland D. Oncogenes in myeloproliferative disorders. Cell cycle 2007;6:550-66. PMid: 17351342. http://dx.doi.org/10.4161/cc.6.5.3919

[64] Matsunaga T, Takemoto N, Sato T, Takimoto R, Tanaka I, Fujimi A, Akiyama T, Kuroda H, Kawano Y, Kobune M, Kato J, Hirayama Y, Sakamaki S, Kohda K, Miyake K, Niitsu Y. Interaction between leukemic-cell VLA-4 and stromal fibronectin is a decisive factor for minimal residual disease of acute myelogenous leukemia. Nat Med 2003;9:1158-65. PMid: 12897778. http://dx.doi.org/10.1038/nm909 
[65] R.L. Sparrow, E. O Flaherty, TM. Blanksby, J. Szer, and MB. Van Der Weyden. "Perturbation in the ability of bone marrow stroma from patients with acute myeloid leukemia but not chronic myeloid leukemia to support normal early hematopoietic progenitor cells.” Leuk Res. 1997; vol.21:pp.29-36. http://dx.doi.org/10.1016/S0145-2126(96)00068-9

[66] Lisovsky MY, Savchenko VG. Defect of stromal microenvironment in long term bone marrow cultures of patients with acute and chronic myelogenous leukemias. Leuk Lymphoma 1995;19:145-52. PMid: 8574161. http://dx.doi.org/10.3109/10428199509059669

[67] Burger JA, Spoo A, Dwenger A, Burger M, Behringer D. CXCR4 chemokine receptors (CD184) and alpha4beta1 integrins mediate spontaneous migration of human $\mathrm{CD} 34+$ progenitors and acute myeloid leukaemia cells beneath marrow stromal cells (pseudoemperipolesis). Br J Haematol 2003;122:579-89. PMid: 12899713. http://dx.doi.org/10.1046/j.1365-2141.2003.04466.x

[68] Vila L, Thomas X, Campos L, Sabido O, Archimbaud E. Expression of VLA molecules on acute leukemia cells: relationship with disease characteristics. Exp Hematol 1995;23:514-18. PMid: 7768307.

[69] Bendall LJ, Kortlepel K, Gottlieb DJ. Human acute myeloid leukemia cells bind to bone marrow stroma via a combination of beta-1 and beta-2 integrin mechanisms. Blood 1993;82:3125-32. PMid: 7693037.

[70] Liesveld JL, Winslow JM, Frediani KE, Ryan DH, Abboud CN. Expression of integrins and examination of their adhesive function in normal and leukemic hematopoietic cells. Blood 1993;81:112-21. PMid: 7678062.

[71] Kortlepel K, Bendall LJ, Gottlieb DJ. Human acute myeloid leukaemia cells express adhesion proteins and bind to bone marrow fibroblast monolayers and extracellular matrix proteins. Leukemia 1993;7:1174-79. PMid: 8350618.

[72] Reuss-Borst MA, Bühring HJ, Klein G, Müller CA. Adhesion molecules on CD34+ hematopoietic cells in normal human bone marrow and leukemia. Ann Hematol 1992;65:169-74. PMid: 1384721. http://dx.doi.org/10.1007/BF01703110

[73] Denkers IA, de Jong-de Boer TJ, Beelen RH, Ossenkoppele GJ, Langenhuijsen MM. VLA molecule expression may be involved in the release of acute myeloid leukaemic cells from the bone marrow. Leuk Res 1992;16: 469-74. http://dx.doi.org/10.1016/0145-2126(92)90172-4

[74] Becker PS, Kopecky KJ, Wilks AN, Chien S, Harlan JM, Willman CL, Petersdorf SH, Stirewalt DL, Papayannopoulou T, Appelbaum FR. Very late antigen-4 function of myeloblasts correlates with improved overall survival for patients with acute myeloid leukemia. Blood 2009;113:866-74. PMid: 18927435. http://dx.doi.org/10.1182/blood-2007-12-124818

[75] Bendall LJ, Bradstock KF, Gottlieb DJ. Expression of CD44 variant exons in acute myeloid leukemia is more common and more complex than that observed in normal blood, bone marrow or CD34+ cells. Leukemia 2000;14:239-46. PMid: 10914548. http://dx.doi.org/10.1038/sj.leu.2401830

[76] Legras S, Günthert U, Stauder R, Curt F, Oliferenko S, Kluin-Nelemans HC, Marie JP, Proctor S, Jasmin C, Smadja-Joffe F. A strong expression of CD44-6v correlates with shorter survival of patients with acute myeloid leukemia. Blood 1998;91:3401-13. PMid: 9558399.

[77] Jin L, Hope KJ, Zhai Q, Smadja-Joffe F, Dick JE. Targeting of CD44 eradicates human acute myeloid leukemic stem cells. Nat Med 2006;12:1167-74. PMid: 16998484. http://dx.doi.org/10.1038/nm1483

[78] Gadhoum Z, Delaunay J, Maquarre E, Durand L, Lancereaux V, Qi J, Robert-Lezenes J, Chomienne C, Smadja-Joffe F. The effect of anti-CD44 monoclonal antibodies on differentiation and proliferation of human acute myeloid leukemia cells. Leuk Lymphoma 2004;45:1501-10. http://dx.doi.org/10.1080/1042819042000206687

[79] Charrad RS, Gadhoum Z, Qi J, Glachant A, Allouche M, Jasmin C, Chomienne C, Smadja-Joffe F. Effects of anti-CD44 monoclonal antibodies on differentiation and apoptosis of human myeloid leukemia cell lines. Blood 2002;99:290-99. PMid: 11756184. http://dx.doi.org/10.1182/blood.V99.1.290

[80] Charrad RS, Li Y, Delpech B, Balitrand N, Clay D, Jasmin C, Chomienne C, Smadja-Joffe F. Ligation of the CD44 adhesion molecule reverses blockage of differentiation in human acute myeloid leukemia. Nat Med 1999;5:669-76. PMid: 10371506. http://dx.doi.org/10.1038/9518

[81] Salesse S, Verfaillie CM. Mechanisms underlying abnormal trafficking and expansion of malignant progenitors in CML: BCR/ABL-induced defects in integrin function in CML. Oncogene 2002;21:8605-11. PMid: 12476307. http://dx.doi.org/10.1038/sj.onc.1206088 
[82] Jiang Y, Zhao RC, Verfaillie CM. Abnormal integrin-mediated regulation of chronic myelogenous leukemia CD34+ cell proliferation: $\mathrm{BCR} / \mathrm{ABL}$ up-regulates the cyclin-dependent kinase inhibitor, $\mathrm{p} 27 \mathrm{Kip}$, which is relocated to the cell cytoplasm and incapable of regulating cdk2 activity. Proc Natl Acad Sci U S A 2000;97:10538-43. PMid: 10973491.

http://dx.doi.org/10.1073/pnas.190104497

[83] Lundell BI, McCarthy JB, Kovach NL, Verfaillie CM. Activation of beta1 integrins on CML progenitors reveals cooperation between betal integrins and CD44 in the regulation of adhesion and proliferation. Leukemia. 1997;11:822-29. PMid: 9177435. http://dx.doi.org/10.1038/sj.leu.2400653

[84] Bhatia R, Wayner EA, McGlave PB, Verfaillie CM. Interferon-alpha restores normal adhesion of chronic myelogenous leukemia hematopoietic progenitors to bone marrow stroma by correcting impaired beta 1 integrin receptor function. J Clin Invest 1994;94:384-91. PMid: 7518835. http://dx.doi.org/10.1172/JCI117333

[85] Verfaillie CM, McCarthy JB, McGlave PB. Mechanisms underlying abnormal trafficking of malignant progenitors in chronic myelogenous leukemia. Decreased adhesion to stroma and fibronectin but increased adhesion to the basement membrane components laminin and collagen type IV. J Clin Invest 1992;90: 1232-41. PMid: 1383271. http://dx.doi.org/10.1172/JCI115985

[86] Gordon MY, Dowding CR, Riley GP, Goldman JM, Greaves MF. Altered adhesive interactions with marrow stroma of haematopoietic progenitor cells in chronic myeloid leukaemia. Nature 1987;328:342-44. PMid: 3474529. http://dx.doi.org/10.1038/328342a0

[87] Ghaffari S, Dougherty GJ, Lansdorp PM, Eaves AC, Eaves CJ. Differentiation-associated changes in CD44 isoform expression during normal hematopoiesis and their alteration in chronic myeloid leukemia. Blood 1995;86:2976-85. PMid: 7579390.

[88] Hazlehurst LA, Argilagos RF, Dalton WS. Beta1 integrin mediated adhesion increases Bim protein degradation and contributes to drug resistance in leukaemia cells. Br J Haematol 2007;136:269-75. PMid: 17233818. http://dx.doi.org/10.1111/j.1365-2141.2006.06435.x

[89] Damiano JS, Hazlehurst LA, Dalton WS. Cell adhesion-mediated drug resistance (CAM-DR) protects the K562 chronic myelogenous leukemia cell line from apoptosis induced by BCR/ABL inhibition, cytotoxic drugs, and gamma-irradiation. Leukemia 2001;15:1232-39. PMid: 11480565. http://dx.doi.org/10.1038/sj.leu.2402179

[90] Hewson J, Bianchi A, Bradstock K, Makrynikola V, Gottlieb D. Ultrastructural changes during adhesion and migration of pre-B lymphoid leukaemia cells within bone marrow stroma. Br J Haematol. 1996;92:77-87. PMid: 8562415. http://dx.doi.org/10.1046/j.1365-2141.1996.00291.x

[91] Messinger Y, Chelstrom L, Gunther R, Uckun FM. Selective homing of human leukemic B-cell precursors to specific lymphohematopoietic microenvironments in SCID mice: a role for the beta 1 integrin family surface adhesion molecules VLA-4 and VLA-5. Leuk Lymphoma 1996;23:61-69. PMid: 9021687. http://dx.doi.org/10.3109/10428199609054803

[92] Makrynikola V, Bianchi A, Bradstock K, Gottlieb D, Hewson J. Migration of acute lymphoblastic leukemia cells into human bone marrow stroma. Leukemia 1994; 8:1734-43. PMid: 7523799.

[93] Bradstock K, Makrynikola V, Bianchi A, Byth K. Analysis of the mechanism of adhesion of precursor-B acute lymphoblastic leukemia cells to bone marrow fibroblasts. Blood 1993;82:3437-44. PMid: 7694686.

[94] Juneja HS, Schmalsteig FC, Lee S, Chen J. Vascular cell adhesion molecule-1 and VLA-4 are obligatory adhesion proteins in the heterotypic adherence between human leukemia/lymphoma cells and marrow stromal cells. Exp Hematol 1993;21:444-50. PMid: 7680000.

[95] Juneja HS, Rajaraman S, Gay RE, Gay S, Schmalsteig FC. Characterization of heterotypic adherence between transformed human lymphoblastic cells and marrow stromal cells: VCAM-1 is a ligand for one of the leukemia cell adhesion proteins. Exp Hematol 1992;20:1263-70. PMid: 1283595.

[96] Bendall LJ, Nilsson SK, Khan NI, James A, Bonnet C, Lock RB, Papa R, Bradstock KF, Gottlieb DJ. Role of CD44 variant exon 6 in acute lymphoblastic leukaemia: association with altered bone marrow localisation and increased tumour burden. Leukemia 2004;18:1308-11. PMid: 15152268. http://dx.doi.org/10.1038/sj.leu.2403393

[97] Ryan DH. Adherence of normal and neoplastic human B cell precursors to the bone marrow microenvironment. Blood cells 1993;19:225-41. PMid: 7906154.

[98] Vincent AM, Cawley JC, Burthem J. Integrin function in chronic lymphocytic leukemia. Blood 1996;87:4780-88. PMid: 8639849. 
[99] de la Fuente MT, Casanova B, Moyano JV, Garcia-Gila M, Sanz L, Garcia-Marco J, Silva A, Garcia-Pardo A. Engagement of alpha4beta1 integrin by fibronectin induces in vitro resistance of B chronic lymphocytic leukemia cells to fludarabine. J Leukoc Biol 2002;71:495-502. PMid:11867687

[100]Plate JM, Long BW, Kelkar SB. Role of beta2 integrins in the prevention of apoptosis induction in chronic lymphocytic leukemia B cells. Leukemia 2000;14:34-39. http://dx.doi.org/10.1038/sj.leu.2401621

[101]de la Fuente MT, Casanova B, Garcia-Gila M, Silva A, Garcia-Pardo A. Fibronectin interaction with alpha4beta1 integrin prevents apoptosis in B cell chronic lymphocytic leukemia: correlation with Bcl-2 and Bax. Leukemia 1999;13:266-74. PMid: 10025901. http://dx.doi.org/10.1038/sj.leu.2401275

[102]Lagneaux L, Delforge A, De Bruyn C, Bernier M, Bron D. Adhesion to bone marrow stroma inhibits apoptosis of chronic lymphocytic leukemia cells. Leuk Lymphoma 1999;35:445-53. http://dx.doi.org/10.1080/10428199909169609

[103]Domingo A, González-Barca E, Castellsagué X, Fernandez-Sevilla A, Grañena A, Crespo N, Ferrán C. Expression of adhesion molecules in 113 patients with B-cell chronic lymphocytic leukemia: relationship with clinico-prognostic features. Leuk Res 1997;21:67-73. http://dx.doi.org/10.1016/S0145-2126(96)00076-8

[104]Herishanu Y, Gibellini F, Njuguna N, Hazan-Halevy I, Farooqui M, Bern S, Keyvanfar K, Lee E, Wilson W, Wiestner A. Activation of CD44, a receptor for extracellular matrix components, protects chronic lymphocytic leukemia cells from spontaneous and drug induced apoptosis through MCL-1. Leuk Llymphoma 2011; 52:1758-69. http://dx.doi.org/10.3109/10428194.2011.569962

[105]Eistere W, Hilbe W, Stauder R, Bechter O, Fend F, J Thaler. An aggressive subtype of B-CLL is characterized by strong CD44 expression and lack of CD11c. Br J Haemat 1996;93:661-69. http://dx.doi.org/10.1046/j.1365-2141.1996.d01-1704.x

[106]Asosingh K, Vankerkhove V, Van Riet I, Van Camp B, Vanderkerken K. Selective in vivo growth of lymphocyte functionassociated antigen-1-positive murine myeloma cells. Involvement of function-associated antigen-1-mediated homotypic cell-cell adhesion. Exp Hematol 2003;31:48-55. http://dx.doi.org/10.1016/S0301-472X(02)00970-0

[107]Kawano MM, Huang N, Tanaka H, Ishikawa H, Sakai A, Tanabe O, Nobuyoshi M, Kuramoto A. Homotypic cell aggregations of human myeloma cells with ICAM-1 and LFA-1 molecules. Br J Haematol 1991;79:583-88. PMid: 1685327. http://dx.doi.org/10.1111/j.1365-2141.1991.tb08085.x

[108]Parmo-Cabañas M, Bartolomé RA, Wright N, Hidalgo A, Drager AM, Teixidó J. Integrin alpha4beta1 involvement in stromal cell-derived factor-1alpha-promoted myeloma cell transendothelial migration and adhesion: role of cAMP and the actin cytoskeleton in adhesion. Exp Cell Res 2004;294:571-80. PMid: 15023543. http://dx.doi.org/10.1016/j.yexcr.2003.12.003

[109]Sanz-Rodríguez F, Hidalgo A, Teixidó J. Chemokine stromal cell-derived factor-1alpha modulates VLA-4 integrin-mediated multiple myeloma cell adhesion to CS-1/fibronectin and VCAM-1. Blood 2001;97:346-51. PMid: 11154207. http://dx.doi.org/10.1182/blood.V97.2.346

[110]Kibler C, Schermutzki F, Waller HD, Timpl R, Müller CA, Klein G. Adhesive interactions of human multiple myeloma cell lines with different extracellular matrix molecules. Cell Adhes Commun 1998;5:307-23. http://dx.doi.org/10.3109/15419069809040300

[111]Kim I, Uchiyama H, Chauhan D, Anderson KC. Cell surface expression and functional significance of adhesion molecules on human myeloma-derived cell lines. Br J Haematol 1994;87:483-93. PMid: 7993788. http://dx.doi.org/10.1111/j.1365-2141.1994.tb08302.x

[112]Pellat-Deceunynck C, Barillé S, Puthier D, Rapp MJ, Harousseau JL, Bataille R, Amiot M. Adhesion molecules on human myeloma cells: significant changes in expression related to malignancy, tumor spreading, and immortalization. Cancer Res 1995;55:3647-53. PMid: 7543019.

[113]Noborio-Hatano K, Kikuchi J, Takatoku M, Shimizu R, Wada T, Ueda M, Nobuyoshi M, Oh I, Sato K, Suzuki T, Ozaki K, Mori M, Nagai T, Muroi K, Kano Y, Furukawa Y, Ozawa K. Bortezomib overcomes cell-adhesion-mediated drug resistance through downregulation of VLA-4 expression in multiple myeloma. Oncogene 2009; 28:231-42. PMid: 18850009. http://dx.doi.org/10.1038/onc.2008.385

[114]Damiano JS, Dalton WS. Integrin-mediated drug resistance in multiple myeloma. Leuk Lymphoma 2000;38:71-81. PMid:10811449 
[115]Damiano JS, Cress AE, Hazlehurst LA, Shtil AA, Dalton WS. Cell adhesion mediated drug resistance (CAM-DR): role of integrins and resistance to apoptosis in human myeloma cell lines. Blood 1999;93:1658-67. PMid:10029595.

[116]Adamia S, Reiman T, Crainie M, Mant MJ, Belch AR, Pilarski LM. Intronic splicing of hyaluronan synthase 1 (HAS1): a biologically relevant indicator of poor outcome in multiple myeloma. Blood 2005;105:4836-44. PMid: 15731173. http://dx.doi.org/10.1182/blood-2004-10-3825

[117]Liebisch P, Eppinger S, Schöpflin C, Stehle G, Munzert G, Döhner H, Schmid M. CD44v6, a target for novel antibody treatment approaches, is frequently expressed in multiple myeloma and associated with deletion of chromosome arm 13q. Haematologica 2005;90:489-93. PMid:15820944.

[118]Crainie M, Belch AR, Mant MJ, Pilarski LM. Overexpression of the receptor for hyaluronan-mediated motility (RHAMM) characterizes the malignant clone in multiple myeloma: identification of three distinct RHAMM variants. Blood 1999;93:1684-96. PMid: 10029598.

[119]van Driel M, Günthert U, Stauder R, Joling P, Lokhorst HM, Bloem AC. CD44 isoforms distinguish between bone marrow plasma cells from normal individuals and patients with multiple myeloma at different stages of disease. Leukemia. 1998;12:1821-28. PMid: 9823960. http://dx.doi.org/10.1038/sj.leu.2401179

[120]Masellis-Smith A, Belch AR, Mant MJ, Turley EA, Pilarski LM. Hyaluronan-dependent motility of B cells and leukemic plasma cells in blood, but not of bone marrow plasma cells, in multiple myeloma: alternate use of receptor for hyaluronan-mediated motility (RHAMM) and CD44. Blood 1996;87:1891-99. PMid: 8634437.

[121]Yang Y, MacLeod V, Dai Y, Khotskaya -Sample Y, Shriver Z, Venkataraman G, Sasisekharan R, Naggi A, Torri G, Casu B, Vlodavsky I, Suva LJ, Epstein J, Yaccoby S, Shaughnessy JD, Barlogie B, Sanderson RD. The syndecan-1 heparan sulfate proteoglycan is a viable target for myeloma therapy. Blood 2007;110:2041-48. PMid: 19583895.

[122] Yang Y, Macleod V, Miao HQ, Theus A, Zhan F, Shaughnessy JD, Sawyer J, Li JP, Zcharia E, Vlodavsky I, Sanderson RD. Heparanase enhances syndecan-1 shedding: a novel mechanism for stimulation of tumor growth and metastasis. J Biol Chem 2007;282:13326-31. PMid: 17347152. http://dx.doi.org/10.1074/jbc.M611259200

[123] Dhodapkar MV, Abe E, Theus A, Lacy M, Langford JK, Barlogie B, Sanderson RD. Syndecan-1 is a multifunctional regulator of myeloma pathobiology: control of tumor cell survival, growth, and bone cell differentiation. Blood 1998; 91:2679-88. PMid:9531576

[124]Comoglio PM, Trusolino L. Cancer: the matrix is now in control. Nat Med 2005;11:1156-59. PMid: 16270068. http://dx.doi.org/10.1038/nm1105-1156

[125]Dührsen U, Hossfeld DK. Stromal abnormalities in neoplastic bone marrow diseases. Ann Hematol 1996;73:53-70. http://dx.doi.org/10.1007/s002770050203

[126]Walkley CR, Olsen GH, Dworkin S, Fabb SA, Swann J, McArthur GA, Westmoreland SV, Chambon P, Scadden DT, Purton LE. A microenvironment-induced myeloproliferative syndrome caused by retinoic acid receptor gamma deficiency. Cell 2007;129:1097-110. PMid: 17574023. http://dx.doi.org/10.1016/j.cell.2007.05.014

[127]Walkley CR, Shea JM, Sims NA, Purton LE, Orkin SH. Rb regulates interactions between hematopoietic stem cells and their bone marrow microenvironment. Cell 2007;129:1081-95. PMid: 17574022. http://dx.doi.org/10.1016/j.cell.2007.03.055

[128]Dameshek W. Some speculations on the myeloproliferative syndromes. Blood 1951;6:372-75. PMid: 14820991.

[129]Tefferi A, Gilliland G. Classification of chronic myeloid disorders: from Dameshek towards a semi-molecular system. Best Pract Res Clin Haematol 2006;19:365-85. http://dx.doi.org/10.1016/j.beha.2005.07.001

[130]Michiels JJ, Thiele J. Clinical and pathological criteria for the diagnosis of essential thrombocythemia, polycythemia vera, and idiopathic myelofibrosis (agnogenic myeloid metaplasia). Int J Hematol, 2002;76:133-45. PMid: 12215011.

http://dx.doi.org/10.1007/BF02982575

[131]Michiels JJ, De Raeve H, Hebeda K, Lam KH, Berneman Z, Schroyens W, Schwarz J. WHO bone marrow features and European clinical, molecular, and pathological (ECMP) criteria for the diagnosis of myeloproliferative disorders. Leuk Res 2007;31:1031-38. PMid: 17367853. http://dx.doi.org/10.1016/j.leukres.2007.01.021 
[132]Michiels JJ. Bone marrow histopathology and biological markers as specific clues to the differential diagnosis of essential thrombocythemia, polycythemia vera and prefibrotic or fibrotic agnogenic myeloid metaplasia. Hematol J 2004;5:93-102. PMid: 15048058. http://dx.doi.org/10.1038/sj.thj.6200368

[133]Schmitz B, Thiele J, Otto F, Farahmand P, Henze F, Frimpong S, Wickenhauser C, Fischer R. Evidence for integrin receptor involvement in megakaryocyte-fibroblast interaction: a possible pathomechanism for the evolution of myelofibrosis. J Cell Physiol 1998;176:445-55. http://dx.doi.org/10.1002/(SICI)1097-4652(199809)176:3<445::AID-JCP1>3.0.CO;2-O

[134]Kuter DJ, Bain B, Mufti G, Bagg A, Hasserjian RP. Bone marrow fibrosis: pathophysiology and clinical significance of increased bone marrow stromal fibres. Br J Haematol 2007;139:351-62. PMid: 17910625.

http://dx.doi.org/10.1111/j.1365-2141.2007.06807.x

[135]Schmitt A, Jouault H, Guichard J, Wendling F, Drouin A, Cramer EM. Pathologic interaction between megakaryocytes and polymorphonuclear leukocytes in myelofibrosis. Blood 2000;96:1342-47. PMid: 10942376.

[136]Thiele J, Kvasnicka HM. CD34+ stem cells in chronic myeloproliferative disorders. Histol Histopathol 2002;17:507-21. PMid:11962756

[137]Wang JC. Importance of plasma matrix metalloproteinases (MMP) and tissue inhibitors of metalloproteinase (TIMP) in development of fibrosis in agnogenic myeloid metaplasia. Leuk Lymphoma 2005; 46:1261-68. http://dx.doi.org/10.1080/10428190500126463

[138]Nolte F, Hofmann WK. Myelodysplastic syndromes: molecular pathogenesis and genomic changes. Ann Hematol 2008;87:777-95. PMid: 18516602. http://dx.doi.org/10.1007/s00277-008-0502-z

[139]Foucar K, Langdon RM, Armitage JO, Olson DB, Carroll TJ. Myelodysplastic syndromes. A clinical and pathologic analysis of 109 cases. Cancer 1985;56: 553-61. http://dx.doi.org/10.1002/1097-0142(19850801)56:3<553::AID-CNCR2820560323>3.0.CO;2-Q

[140]Braun T, Carvalho G, Grosjean J, Ades L, Fabre C, Boehrer S, Debili N, Fenaux P, Kroemer G. Differentiating megakaryocytes in myelodysplastic syndromes succumb to mitochondrial derangement without caspase activation. Apoptosis. 2007;12:1101-08. PMid: 17245643. http://dx.doi.org/10.1007/s10495-006-0030-z

[141]Kerbauy DB, Deeg HJ. Apoptosis and antiapoptotic mechanisms in the progression of myelodysplastic syndrome. Exp Hematology 2007;35:1739-46. PMid: 17976524. http://dx.doi.org/10.1016/j.exphem.2007.09.007

[142]Westwood NB, Mufti GJ. Apoptosis in the myelodysplastic syndromes. Curr Hematol Rep 2003;2:186-92. PMid: 12901339.

[143]Parker JE, Fishlock KL, Mijovic A, Czepulkowski B, Pagliuca A, Mufti GJ. 'Low-risk myelodysplastic syndrome is associated with excessive apoptosis and an increased ratio of pro- versus anti-apoptotic bcl-2-related proteins. Br J Haematol 1998;103:1075-82. PMid: 9886323. http://dx.doi.org/10.1046/j.1365-2141.1998.01114.x

[144]Delforge M, Raets V, Van Duppen V, Vandenberghe P, Boogaerts M. CD34+ marrow progenitors from MDS patients with high levels of intramedullary apoptosis have reduced expression of alpha4beta1 and alpha5beta1 integrins. Leukemia 2005;19:57-63. PMid:15510209

[145]Raza A, Gezer S, Mundle S, Gao XZ, Alvi S, Borok R, Rifkin S, Iftikhar A, Shetty V, Parcharidou A. Apoptosis in bone marrow biopsy samples involving stromal and hematopoietic cells in 50 patients with myelodysplastic syndromes. Blood 1995;86:268-76. PMid:7795232

[146]Tauro S, Hepburn MD, Bowen DT, Pippard MJ Assessment of stromal function, and its potential contribution to deregulation of hematopoiesis in the myelodysplastic syndromes. Haematologica 2001;86:1038-45. PMid:11602409

[147]Tennant GB, Walsh V, Truran LN, Edwards P, Mills KI, Burnett AK. Abnormalities of adherent layers grown from bone marrow of patients with myelodysplasia. Br J Haematol. 2000;111:853-62. PMid: 11122147. http://dx.doi.org/10.1111/j.1365-2141.2000.02467.x

[148]Tricot G, De Bock R, Dekker AW, Boogaerts MA, Peetermans M, Punt K, Verwilghen RL. Low dose cytosine arabinoside (Ara C) in myelodysplastic syndromes. Br J Haematol 1984;58:231-40. PMid: 6591945. http://dx.doi.org/10.1111/j.1365-2141.1984.tb06081.x 
[149]Tricot G, De Wolf-Peeters C, Vlietinck R, Verwilghen RL. Bone marrow histology in myelodysplastic syndromes. II. Prognostic value of abnormal localization of immature precursors in MDS. Br J Haematol 1984;58:217-25. PMid: 6477833. http://dx.doi.org/10.1111/j.1365-2141.1984.tb06079.x

[150]Borojevic R, Roela RA, Rodarte RS, Thiago LS, Pasini FS, Conti FM, Rossi M, Reis LF, Lopes LF, Brentani MM. Bone marrow stroma in childhood myelodysplastic syndrome: composition, ability to sustain hematopoiesis in vitro, and altered gene expression. Leuk Res 2004;28:831-44. PMid: 15203281. http://dx.doi.org/10.1016/j.leukres.2003.11.019

[151]Flores-Figueroa E, Gutiérrez-Espíndola G, Montesinos JJ, Arana-Trejo RM, Mayani H. In vitro characterization of hematopoietic microenvironment cells from patients with myelodysplastic syndrome. Leuk Res 2002; 26:677-86. http://dx.doi.org/10.1016/S0145-2126(01)00193-X

[152]Boruchov AM. Thrombocytopenia in myelodysplastic syndromes and myelofibrosis. Semin Hematol 2009;46:S37-43. PMid: 19245933. http://dx.doi.org/10.1053/j.seminhematol.2008.12.001

[153]Tang G, Wang SA, Menon M, Dresser K, Woda BA, Hao S. High-level CD34 expression on megakaryocytes independently predicts an adverse outcome in patients with myelodysplastic syndromes. Leuk Res 2011;35:766-70. PMid: 21367453. http://dx.doi.org/10.1016/j.leukres.2011.01.009

[154]Buccisano F, Maurillo L, Tamburini A, Del Poeta G, Del Principe MI, Ammatuna E, Consalvo MI, Campagna S, Ottaviani L, Sarlo C, Renzi D, Faccia S, Fraboni D, Lo Coco F, Amadori S, Venditti A. Evaluation of the prognostic relevance of L-selectin and ICAM1 expression in myelodysplastic syndromes. Eur J Haematol 2008;80:107-714. PMid: 18028430.

[155]Loeffler-Ragg J, Germing U, Sperr WR, Herrmann H, Zwierzina H, Valent P, Ulmer H, Stauder R. Serum CD44 levels predict survival in patients with low-risk myelodysplastic syndromes. Crit Rev Oncol Hematol 2011;78:150-61. PMid: 20580567. http://dx.doi.org/10.1016/j.critrevonc.2010.05.008

[156]Moldoveanu E, Moicean A, Vidulescu C, Marta D, Colita A. Apoptotic rate in patients with myelodisplastic syndrome treated with modulatory compounds of pro-apoptotic cytokines. J Cell Mol Med 2003;7:313-21. PMid: 14594556. http://dx.doi.org/10.1111/j.1582-4934.2003.tb00232.x

[157]KF Bradstock, DJ Gottlieb. Interaction of acute leukemia cells with the bone marrow microenvironment: implications for control of minimal residual disease. Leuk Lymphoma 1995;18:1-16. PMid: 8580810. http://dx.doi.org/10.3109/10428199509064917

[158]Berger M, Motta C, Boiret N, Aublet-Cuvelier B, Bonhomme J, Travade P. Membrane fluidity and adherence to extracellular matrix components are related to blast cell count in acute myeloid leukemia. Leuk Lymphoma 1994;15:297-302. PMid: 7866278. http://dx.doi.org/10.3109/10428199409049727

[159]Castro-Malaspina H, Jhanwar SC. Properties of myelofibrosis-derived fibroblasts. Prog Clin Biol Res 1984;154:307-22. PMid:6382300.

[160]Lane WJ, Dias S, Hattori K, Heissig B, Choy M, Rabbany SY, Wood J, Moore MA, Rafii S. Stromal-derived factor 1-induced megakaryocyte migration and platelet production is dependent on matrix metalloproteinases. Blood 2000;96:4152-59. PMid:11110686

[161]Schick PK, Wojenski CM, Bennett VD, Ivanova T. The synthesis and localization of alternatively spliced fibronectin EIIIB in resting and thrombin-treated megakaryocytes. Blood 1996;87:1817-23. PMid:8634428

[162]Muth M, Engelhardt BM, Kröger N, Hussein K, Schlué J, Büsche G, Kreipe HH, Bock O. Thrombospondin-1 (TSP-1) in primary myelofibrosis (PMF) - a megakaryocyte-derived biomarker which largely discriminates PMF from essential thrombocythemia. Ann Hematol 2011;90:33-40. PMid: 20625903. http://dx.doi.org/10.1007/s00277-010-1024-Z

[163]Cachaço AS, Carvalho T, Santos AC, Igreja C, Fragoso R, Osório C, Ferreira M, Serpa J, Correia S, Pinto-do-O P, Dias S. TNF-alpha regulates the effects of irradiation in the mouse bone marrow microenvironment. PloS one 2010;5: e8980. PMid: 20126546. http://dx.doi.org/10.1371/journal.pone.0008980 